\title{
Reflections on the Global Financial System"
}

\author{
Michel CAMDESSLS \\ International Monetary lund
}

The world is poised to enter a new end of human history as it sets forth into the tulenty-first century. The new times promise unparalleled hope and breathataing advances in every facet of life, but at the same time it can exact stiff penalties and suffering for those who fail to comprehend the unpredictable and volatile natune of today's interwouten global economys for the internutional Monetary Fund (IMF), whose main duties include safeguanding the global economic and financial system, the current situation in Asia is especially alarming since most of the countries afflicted by this doimturn, have broadly enjoyed growth unrivalled by the rest of the uorld for the past fen decades. Since the crash, however; the IMF has begun to examine and analyze the woes and defuciencies that bave caused this disuster to unfold. The risult of the preliminary studies indicatc that the region as a whole suffers from several weatknesses that were not readily apparent during the heydays of rapid development, which includes, the fragile public and private banking and financial structures; an unsustainable accumulation of short-term financing; and the problems associated with governance. Fortunately for the world, the emergency furds and measures endorsed by the IMF were effective in curtailing the precipitous downward spiral of the Asian economies. However; it is not enough to just limit the damage, and the IMF bas been called upon to denise means to prevent a recurrence of such eventualities in the future. To this goal, the IMF is in the process of strengthening the global economic architecture by enhancing surveillance, and developing "tiered responses," that would protect and boliter financial and bunking systerns around the wond from dubious invesments and Loans, while continuing to liberalize intemational capital flows. The era of globalization is at band. It could be said that it is an irrevocable orend. What is important for the world at this juncture is that stable grow th accompanies this ongoing process so that all of mankind can experience it rewards.

\footnotetext{
* Direct all cortespondence to Michel Camdessus, Managing Director of the Intetnational Monetary Fund, Washiogron, D.C. 20431. U.S.A.
} 


\section{Toward a New Financial Architecture for a Globalized World"}

\section{CHANGE IS NEEDED}

$A$ s in the days of the Induscrial Revolution we are now at a defining moment of Ahuman hiscory. The question before us is straigheforward: how to urilize the full potential of globalization to improve the living standards of all-particularly the poorest - while containing the risks it entails, such as those we have seen materialize so brutally in Asia. and those at least oqualty pernicious, even if less spectacular, of the conrinuous marginalization of the poorest countries. What kind of new architecture of the global system could achieve this? "The response must be dectued from a proper analysis of the most recent crises.

Contrary to what we saw during the debc crisis of the 1980)s. the problems in Asia were nor almost exclusively macroeconomic in nature; even if these countries suffered, all of them. from some deficiencies in this respect, by and large they had long track records of successful cconomic management. Rather, in a contoxt dramarically changed by a major ralignment berween the dolkar and the yen, and important differences in short-term yidds, three other factors helped trigget the crisis:

- rhe weaknes: of their public and private banking and financial srructureisi

- higher spending on primary health care and education; alad adequate social protection for the poor, the unempleyed. and other vulnerable groups;

- the creation of a more level plaving field for private scctor activity, by increasing openness, stepping up privatization, dismanting monopolies, and setting up simpler, more transparent regula. tory systctis.

Together with the macroconomic problems, these three major factors had to be addressed for our response to the crisis to be pertinent. If you examine our programs with lhailand, Korea, and Indonesia, you will see that we have tried to deal with these factors, and they will have to be taken into consideration in the future in whatever efforts are undertaken to avoid the recurrence of crises. But even that will not suffice. In view of the enormous buman and economic cost of the Astan crisis, no wonder we hear many radical suggesrions as to how to avoid such losses in the future. There are calls for us to do a better job of predicting and preventing crises, addressing their social impact more effectively, stopping speculators and properly regulating this "casino economy,"

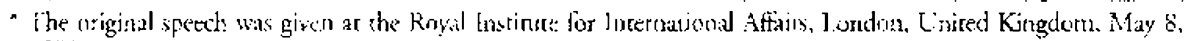
1)
} 
seeing to it that investors bear the full costs of their mistakes, stabilizing the inrernational monetary system, providing for more political accountability of our institution, etc., etc.

We cannot deny the basic justification of these, at times, vociferous calls for change. No doube there are at least some elements of validity in each of them. Taken together they tell us that, at this stage, world public opinion expects its leaders to design and build a new, common house with an audaciously modern architecture, and not limit themselves to some plumbing and interior decorating of the old mansion.

But, as responsible architects, let us start by recognizing the building blocks at hand. Indeed, they are substantial.

\section{SEVEN BUILDING BLOCKS}

The first of these building blocks is the tremendous potential for growth and prosperity globalization provides countries fully integrating into the global economy. Formidable sources of dynamism are there, engendered by new information technologies and unifying financial markets. The qucstion, then, is how to discipline and channel these forces so that growth will be sustainable and more broadly shared and the fundamental desire for greater equity will be more fully satisfied.

The second building block is integration. By integrating themselves into the mainstrean of the globalizing world econony, the ponrest countries will avail themselves of a most powerfil instrument of acceleration of development, while, if they preferred to do it alonc, they would cxpose themsctves to the risks of marginalization, abandoning scveral generations to economic stagnation and povery.

The third busilding block is the universal consensus on the importance of an increasingly open and liberal system of capital flows in order for globalization to deliver on its promises.

The fourth building block is what we condd call the "goiden rule" of transparency, now truly seen as the key for modern managenent, economic success, and rational behavior of gtobal markets.

The fifth is good governance, which is equally esscntial for strong cconomics and properly functioning democracies. No doubt, competing for excellence in governance is the modern face of statesmanlike responsibiliny.

The sixth building block could be a set of standards and codes of best practices; this could require a few words of elaboration. More and more we ubserve an emerging recognition that the global markets still suffer from the kind of anarchy that afflicted our domestic financial markets bere in Furope during the nineteenth and the beginning of the twentieth centuries that is, unvil various scandals and crises led to the creation of such insritutions and rules as securities and exchange commissions, banking supervision, accounting standards, disciosure and prudential rules, and so forth. Our challenge today is to disseminate these good practices in energing markets and to establish similar checks and balances in global markets. 'This could appear an impossible task, as many will pre- 
tend that the absence of rules or regulations of any kind has been at the very origin of the developments of these markets. The world community is now coming to a different view, and looks forward for the definition of international standards and cocles of good practices, which would be progressively disseminated by the IMF through its surveillano, and could help limit the excesses of an international "casino economy."

Last, but not least, the seventh building block is the option for the multilateral approach to handle problems which are now more and more global in nacure. And the key instruments of such an approach will have to be the Bretton Woods institutions themselves. Let me be immodest for a momenc. The experience they have accumulated, the quality of theif staff, their demonstrated ability to address new cconomic hallenges promptly and efficiently make them a major asset of the world community and a central pillar of a new architecture, provided they continue adapting themselves, reforming themselves, to this new world. And suggestions for self-reform are in abundant supply.

These seven building blocks have been neglected or unevenly utilized for too long. Assembled in the right way, they could offer a rock-solid foundation for a new financial syscem. Assembling them, nevertheless, will be hard work, each of them implying that vested interests or perverse practices be challenged. Thus, notwirhstanding our sense of urgency, we are heading here for an evolutionary change: Athena in her helnet will not spring full-grown from the head of Zeus! And, as with all transitions from one cra to another, we can expect risks and uncertainties to persist for some years to come. This makes it all the more urgent to get to work on this new architecture right away.

\section{INITIAL STEPS FOR A NEW ARCHITECTURE}

In fact, a number of significant steps are already under way. At its April meeting, our governing body, the Interim Committee (of Ministers and Central Bank Governors of IMF member countrics), set the broad agenda for the IMF's own work -and its work with others-for the near future. Five areas have been given priority by member governments:

- The central role to be played by the IMF in crisis prevention through its survcillance and its role in encouraging members to strengthen their macroeconomic policies and financial sectors.' The lnterim Commintee suggests that the Fund intensify its work in surveillance of financial sector issues and capital flows, and focks on the risks posed by potentially abrupt reversals of capital fows, especially those of a short-term nature. The Fund is also asked to examine ways to strengthen the monitoring of capital flows, a major and difficult undertaking inderd!

\footnotetext{
'Of course, ir is clear that for IMF surveillance to be effecive, member countries must provide timety', accuratc; and comprehensive data in the Furd. 'The Interim Commintec underscored members' obligation in this regand and suggessed cielaying the Fund's reviews of memher economies when deficiencies in disclusing relevant information to the IMF seriously impecte our surveilance. lndeed, the $G \%$ couneties have die opponumity this week to establish leadership by pledging to convey to the IMF and to publish comprehensive and rimely dara on both gross and ner reserves, induding reserve-selated liabilities and central bank detivative transactions and positions, as well as extemal debt and stata on barking and tinarsial sector heyath.
} 
- Drawing on the lessons from the Asian crisis, and the frustration that contidential warnings from the Fund were not always heeded, the Fund has been asked to develop a "tiered responsc," whereby countries that are believed to be seriously off course in their policies arc given increasingly strong warnings. Addressing an audience in this country, wherc foothall is a way of life, of in sny own councry in advance of the World Cup, I do not noed to emphasize how inportans it is to know exactly when the referee has shown a yellow card and how many yellow cards are per. nitted! We also have the red card in ou Articles of Agreement, but using this card could precipirate the crisis we seek to avoid. So we prefer to use the yellow card.

- The incerin Commintec also called upon the IMF to help manters strengthen their dornescic financial systems by encounging them to develop supervisony and regulatory franeworks that arc consistent with internationilly accepted best practices, as well as strengthened standards for bank and non-bank institutions. Here you will recognize, of course, the "ssandards and good practices" building block. Work in this atea is alteady in progtess in various fora. A norable example is the Basle Commitre's Core Principles for strengthening banking regulation and supervision. which the $\mathrm{MPF}$ is now helping to disseninare to member countries. W'e will now work with other relevan institutions that could be responsible tot developing similar standards in areas such as accounting, auditing, disclosure, asset valuation, baskruptcy, and corporate govemratue. We will also consider how to disseminate such standards to member countries through our survetlance and encourage their adoprion. Working with 3 many instinutions, public and private, in addition to out 182 number countries, will be an ambitious undertaking, but we are ready - and enchusiastic - to play our full part in this new chapter in international cooperation.

In the meantime, the IMF has been applying this standards approach to one of its traditional demains of expertise: fiscal policy. I awe winter, following the suggestion of the Chancellor of Fxchequer, the IMF developed a code of good pracrices on fiscal rransparency to which members will be encouraged to adhere. Iooking ahead, we plan to develop a similar code with respect to financial and monetary policies in cooperation with the approptiate institutions.

- But despite these efforrs at crisis prevention, crises may continue to arise from time co time. In this regard, the lnterim Committce also ceaffirmed both the central role of the Fund in crisis management and the teed to develop more effective procedures to involve the private sector in forestalling or resolving financial crises.

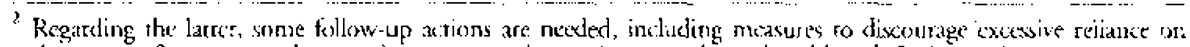
shutt-term financing and screngthen countries' capacit; to withstand sudden shifrs in marker sentienent. Ir:

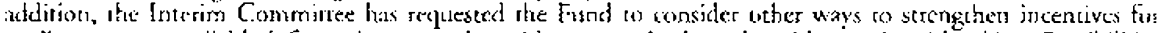
cteditors to use available information to asalyze risks appropriately and avoid cxcessje risk-raking. Possibilirits itsdude antroducieg provisions in homd coneraces regarding bondlolder representation and voting in case of negotiations on bond rescructuring: excending the Fund's policy of providing financing as nember countris in arreats to prisatk: creditors; encouraging strong bankrupicy systems for both domestic and intesnacional capitial

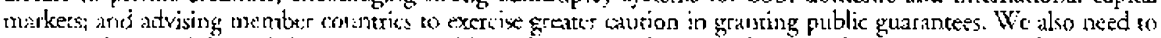

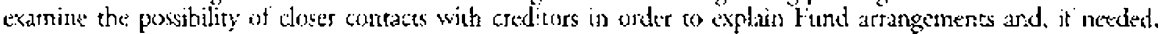

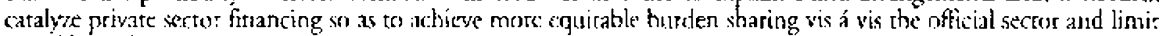
moral hazard.

Establishing clocer conners with private creditors, particuiatly at an early slage of a crisis, raises difficult jisucs; thus, is is not surprising thar the Interin: Committe has not pronounced on this point. Anongy the various options. ]

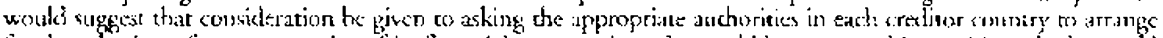
For the selecrion of a representative of its financial communisy, who could be conacted in a crisis and who could

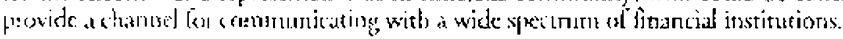




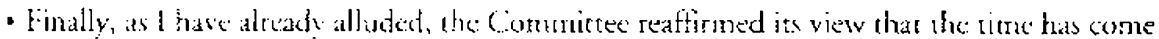

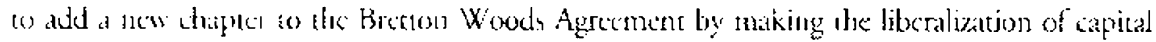

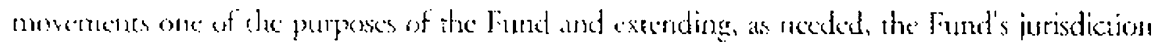
for this propose. Ir requested the Fxecutive Rourd te pursue its work on this issue with determi-

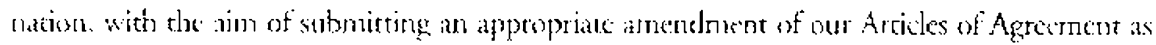
surm as possible.

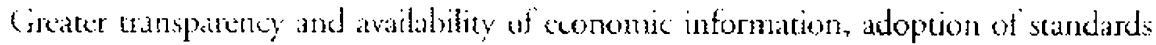
and dissomination of best pratices. a concinuous strengthening of $\mathrm{IMF}$ surveiflanct, the

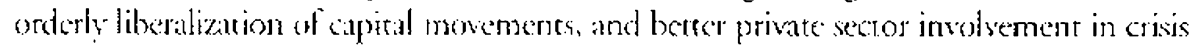
privention and resolution -waken together and utilized ro their full porentials these tirst five pillass could be is very significant concribution to a new findncial architccture much more atcune co dramatically modernizad and ghobalized matkets. I have no doube the $\mathrm{C}$ $7 /$ i-s laders in Bin mingh ham will invite us te buide on this basis. One can even imagine

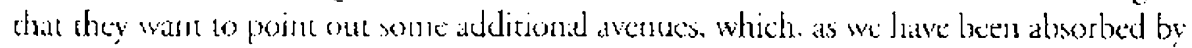

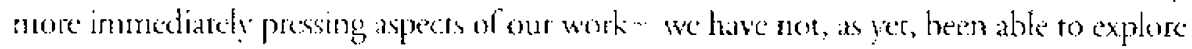
sutticienty:

\section{WHAT NEXI?}

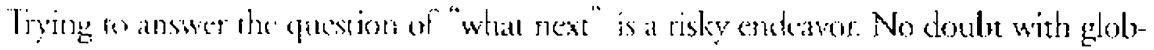
alization unfolding its ofportumiries and risks, new prorities will promytly apture our artention and overtake our presstablished agendas. But is is always better to try to anticipate then, particularly when they reflect problenis that should already have been addessied, he it:

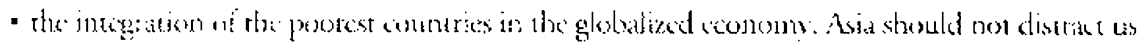

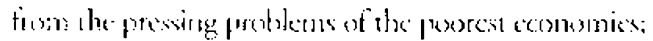

- the stabilization of the incersuriomal moncrany systert; ror

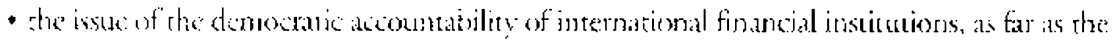
IMt is concormot.

The issue at the integration of the protest onmerice is of course, atready on out agen-

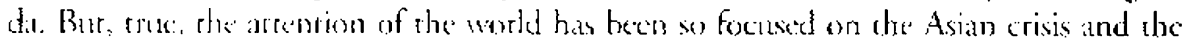
need an andid its recurence that the immense problem of develepment and alleviation of powser: particularly is: Affica, seems to have hoen pot temporarily on a back-burner. This is no longer aticepralla.

In this context. I wels particulaty happy that, in drawing the lessons of an external eral-

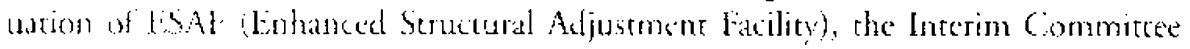

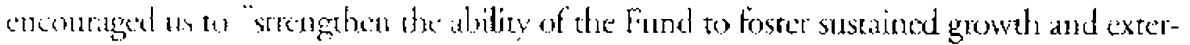

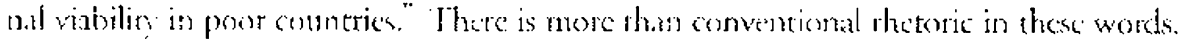
This mention, in a doxmenc wemently deved to the handling of financial crisis. surely 
testifies to the recognition by the world's hinancial leaders that the success or failure of poor countrics in finding their own way coward intcgration and development in an interdependent world will have a major influence on what the twenty-first century will be. This means that the solidity of our new architecture will crucially depend on the way in which, for the poorest countries, monetary and financial strategies, on the one hand, and poverty alleviation strategies, on the other hand, are made mutually reinforcing.

Poverty alleviation is chiefly, of course, the task of the Wotd Bank, the regional developtnent banks, and bilateral donors. Among the latter, it is quite cncouraging, indeed, to see the energy and enchusiasm with which the Brirish Minister for Development-an MP from Birmingham, as a matter of fact- Ms. Clare Short, is promoting the DAC. (Development Assistance Committee) Target of reducing by one half the proportion of the world's population living in extreme poverty by 2015 .

These objectives are ambitious, but they remain realistic, provided industrial countries join forces in stopping the present decline of development assistance and implement their agreed commitunent to support, as needed. countries that truly own their national strategies for sustainable development. Among the latter, I would agree that particular priority be given to post-conflict countries where we nus join forces to give new chances to reconciliation, peace and development. Oheying this same imperative of serving together peace and developnent, I would also suggest that the $G-7 / C_{1}-8$ warmly endorse Mr. Koffi Annaris recommendation to the African Governments to reduce purchases of arms and munitions to 1.5 percent of GDP and maintain zero growth on defense budgets for the next decade. Industrial countries must play their full part in these efforts, and, here, I must share with you my anxiety.

Today's silence on the crisis in official development assistance is profound and distressing. It means that Africa, in particular, must rely chiefly for its economic progress on humanitarian compassion or the benefits of trade. This cannot suffice if human development is to be intensified and accelerated. Yet, at the present juncture, the macroeconomic and structural successes of recent years, precisely in the context of IMF-World Bank supported programs, are creating an opportunity that is too good to miss. Africa has found a way to advance from two decades of negative per capita growth to positive growth in more that forty of its countries. In many African countries, a new generation of leaders is seriously concerned about the need for democratization, protection of human rights, promotion of "good governance," and human development. "Their efforts are in danger of falling shorr, however, because their domestic savings rates are still too low to finance the volume of investments needed to boost thejr rate of growth from approximatcly 5 percent to over? percent, which is not an unrealistic objective; it could be attained and sustained for a long time if local savings were supplemented by an approprate mix of public and private foreign support and if a few key condicions were met, notably :

- continued modernization of the Gamesork for private investment; and

- insprovement in public governance through the total commitrnent of new gowerning teams.

"I hope I am not revealing a sate secrer in) telling you chac she inscribed this on her Christmas card! 
'logether with the World Bank and bilateral donors, we can make a difference. But a strong political impulsion by the world's leaders and the example of their countries coop. crarion to development will be of the essence. May their communique demonstrate their vision and leadership in this domait also.

The stability of the intersational monetany system has been on the agenda for more than 20 years of annual summits. The Asian crisis has bighlighted how disruprive developments in exchange markets can help trigger a erisis. It is in this domain that efforts to strengrthen multilaterd survillance over the international nonetary system could be particutarly frutitul. Moreover, the development of the curo ine a key international currency couk make in major contribution to stability of the overall archirecrume provided that dose cooperation is established among the monetary authorities of the tripolar system that inight taks: shape. Even if it would be premature at this stage to ty to elaborate further on how to maximize the posirive effects of this major innovation, no doubt the new internationat monetary ecpulibrium will thave to be kept under review as a key elconent of the new archiecture. From the ousset, effective neans of andination will have 10 he found ro awod excessive misalignments and dismptive correcrions. The world is fully iustificd in cxpecring a responsible leadership from these major cutroncies blocs, which should be acrively mindful of their global responsibility and resist the tempration of "benign neglect." Fach of thern.

Lastly, at a time when de facto nore and more responsibilities are being given to the intcrational financial institutions, and particularly to the IMfl, the question of their political accoumbability will probatsly be raised with increasing insistence. Indect this quesrion already arises from cime to time, although nor always with fill awatentess of the nature of our institucions and of the prowerful checks and balances already enshrined in their Articles of Agrement. In this context, and as far as the lMF is concerned, is there anything that could be done to strengrhen what one might call the political accountabilifo or legitimaty of our institutions? At this stage, this would requirc an least a firw organirational changes, which would make more explict the tie that hinds ws to the governments we depend on. The IMF could. for instance, encourage its Governors, in generil the Ministers of Finance, ro become more acrively involved in it work, in terms of decison-making and not medely in a consultative capacity in the Interim Committee A sinilar querion faces the 6.7 , which teels the need to embrace emerging market countries, but is unclear about how to go about ir, and finds if difficule co come up with acceptable ways of doosing is parters. The design of a uew anchitecture provides, perhaps, a good ocasion to address these long-aboided questions. Two avenutes condd be explared.

The ites would be to "revialize" the IMH' Interim Commitec. Is could become an essential smucture, because no other can mach the scope of its responsibility and the legitimacy of jes members, who are collectrvely responsible for key developments in the workd economy. At present, however, it is hampered by the riturlism of its meetings and an insufficent awamens of its uniqueness and potential. Ihis is why I think that the sug-

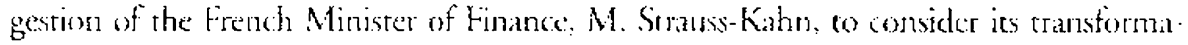
tion inso a "Council" sirh decision-making, mather thatn merly consultative, powers, is 
particularly important. 'This is not a new idea. 'This transformation, pursuant to Article Xil, Section 1 of the Fund's Articles of Agrement, could give it a new start. 'This approach was envisaged under the Jamaica accords, but deferred at the time because of the experimental nature of the Intcrim Commitree. But given the daunting changes that have occurred recently in the world economy, and the fact that the IMF has achieved truly universal stacus with the accession of the transition countries, perhaps the rime has come to consider it. Without grearly altering the operation of the institurion and the pivotal role of its Executive Boad, such a transtornation would give the IMF renewed and very valuable legitimacy for the increasingly difficult tasks it is called upon to perform."

The scond averue, in the same spirit, would consise of making provisions every two yzars for the $G-7 / G-8-$ on the occasion of their meetings - to join the heads of state and government of the 16 countries holding seats on the I.MF and World Bank Execurive Boards to discuss with then and with the heads of those two institutions and the WTO the major economic and financial questions of the day. This new $\mathrm{G}-24$ would have the significann meric of its basic legitinacy, as it would strictly reflect the system of international tepresentation established for monctary and financial affairs in Bretton Woods. This would cleaty represent a step forwat not only in terms of dispelling the current malaise, but also in terms of hastening the akoption of integrated policy responses to the challenges of the globalized economy. The Secretary General of the United Nations should also be invited to participace to take into account the work of the entire family of LN agencies, which contut become a fourth humanitarian and social pillar of the workd system.

Such ideas coukd, of course, be met with skepticism and run up against logistical problems that may seem insurmountable. Nevercheless, they need to be discussed, as they could providc a concrete way of recognizing that each medium-sized or developing country must have a more equitable share of responsibility for the future of the world economy, a share that thry believe is unjustly denied them in the present institutional arrangemens of the intermational financial systcm.

Now, at the end of this andysis of a number of key issues confronting the world economy, it is perhaps appropriate to come back for one minute to the central mexsages of our eminent predecessors of the I dinat Society two hundred years agn. I am told that they included:

- the value of drawing lessons and inspiration from various disciplines and from the experience in different countries:

- che need to establish and disseminate standards so quality would be uphetd and trade would Hourish; and

- a decp concerb for ate social implications of conomic change and a keen desire to improve cducation:

- and of course, a strong sense of purpose and contidence in the promises of their new world.

No doubt these messages could strike a chond wirh many people today, including...-

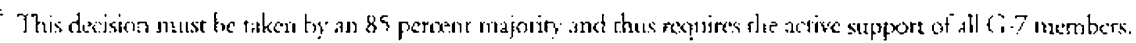


why not? ". the stellar group that will assemble in Birmingtan. May they share these approaches and concerns. Their confidence in the lasting benefits of globalization will be filly justifial as a new workd, bern from the epening of coononice, the unifiation of markets, and the universal avalahility of information and knowledge, has an immense potcntial for high-cquality growth. Nay they also validate their own message of confidence by a clear demonstation of their sense of universal responsibitity and solidarity. 


\section{From the Asian Crisis Toward a New Global Architecture}

\section{What uent wrong in Asiat?}

W e hase all admired the "Asian miracle" hased on saving, prudent fiscal policies, investmen in ptysical and human capital, and the liberalization and opening up --albeic in unequal meature - of economies. The results are there to see, particularly in terms of a reduction in extreme poverty. But there was a dark side, and the lesson from this crisis is that in a globalized counomy a few macrocconomic virtucs are not cnough. Constant vighiance must be mailuained over all the sociocconomic paraneters: yet in each of rhesc countries, there were lapses. The soundness of the banking system in particular must be monitored at all imes; yes, here too, these countries failed, and, what is more, their unsustainable accumulation of short-term financing made them vulnerable to swift changes in market sentimenr. Finally; countries must take great care to ensure that their affairs are conducted in an irreproachable and transparen manter and that all forms of corruption. nepotisn, and lavoritism are shumed: yet, over time in Asia, these afflictiuns tork hokd and owerpowed sistems that were othernvise remarkably successfil.

But let us not single out the Asian countries alone. These blemishes exist to a degree everywher and these countries problems would wo bave reached such proportions if certain firancial insticutions in miajor industrial couturies had not taken excessive risks. there are, however. lessons to be learned here, so I shall return to this point.

\section{What is the IMF doing to contain the risis?}

As soon as it was alled upon-- unfortumately typically, roo late-the IMF helped Korea, Indornesia and Thailand formulate, and adapt as necessary, reform programs aimed at restoring investor confidence, te-cstablishing access to international capital markers, and reversing excensive currency depreciarion. These prograns - I would like ro cmplasize - go far beyond exsoring the major fiscil, monetary. or external balances. Their aim is to serenghere financial systems, improve governance and ransparency, and restore conomic competitiveness through, for example, the climination of monopolies and the moternization of the legal and regulatory environment. To ensure the success of rhese effors. we have marshaled an unprecedented volume of financial support. And in varied ways, we have helped all the countries thoughout the world that were being

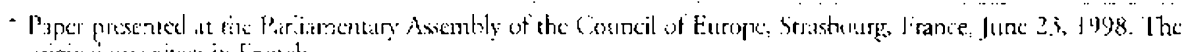
uriguali kis givell it: Fand! 
threatened with contagion to strengthen their equilibria and their structures.

But now, in recent weeks. a new crisis - a crisis within the crisis - has emerged with the dramatic fall of the yen. This new development reflects a serious lack of confidence, provoked by Japan's slaggish reaction to an economic slowdown that is turning into tectssion and the crisis in its financial instimutions. Clearly, the fall of the Japanese yen is not unrefated to the Asian crisis, but it could also seriously jeopardize the ongoing recovery of the cconomies that were hit first. And it adds to the market instability that is again affecting Russia and some emerging economies.

Faced with these devclopments, an immediate, forceful reaction was required. The joint interventions of dhe United States and japan on the foreign exchange market to help the yen regain lost ground were justificd, but the effect will be lasting only if Japan promprly adopts energetic measures for the rehahilitation of irs banking sector, tax relief, public investment, and the opening up and deregulation of its economy. The world cannot stand by. however, and simply wait for the good health of the U.S.economy and the strength of the recovery in convinental Europe to dispel the crisis and restore harmonious, broad-based growuth. So I wotald like to list, if I may, several other urgent tasks facing the international community:

First, we must strengthen the adjustment programs of the countries most severely affected by the crisis in southeast Asia and support their economic recovery. The multilateral institutions - the IMF: World Bank, and Asian Development Bank-have taken on this task. But there is also a need for countrics that have beerl accumulating balance of payments surpluses for some time now, including certain European Linion countries, to recivile those surpluses in the forn of unticd loans to countries in the process of adjustment. I appeal to the European countries - parricularly those with surptuses " to increase their humanitarian aid. As creditors, they should stand ready to grant generous terms for the restructuring of their claims, support the recovery in Asia through new loans-- and. above all, keep their markets open. This will be a good investment in their own furture.

Second, we must strengther policies to improve fiscal managennent, in order to guard against further economic downturns. I'his message applies to all countries, including those now raking the historic step of adopting the euto. It applies in purcicular to the transition countries and certain emerging countries, particularly those in Latin America, which are more vilnerable than others. It applies most especially to Russia, which has also been severely shaken by the crisis and which knows that additional external assistance would provide only scant relief unless accompanied by far-reaching financial adjustment measurcs that arc long orcrdue.

Third, we must help preserve the stability of exchange rates in countries whose acrions may le crucial to market stability, such as (hina and Hong Kong, despite the short-term negarive impace of the crisis on their exports and growth. In these countries, as in Singapore and 'laiwan l'rovince of China, there is a certain margin for fiscal stimulus. which should be used without delay if it becomes necessary.

Lastly, the attention focused on the problems of Asia should be coupled with an cqually determined effor to belp Africa cscape marginalization and acelerate its growth, which is finally positive again after two lost decades. I would like to mention just two 
IMF' iniriatives in this regard:

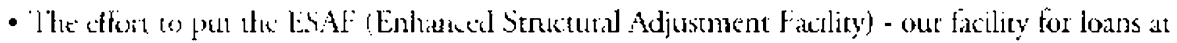
an incera rats of 0 . ficreter on a permanent fouting and increase its effectivencss in terms of growrh and social printicies. The: ESAF is the instrumenc we use to provide financing to the provest countries. Again, I appeal to the European councries. This tacility is one of the correrstones of intentational coopcration. Sou cannot allow it :o be underfinanced.

- Rapid implemetecation of our joine initiative with dic World laank for the heavily indebted poor

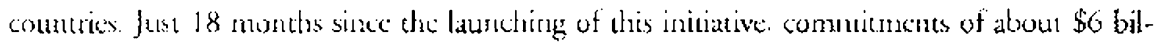

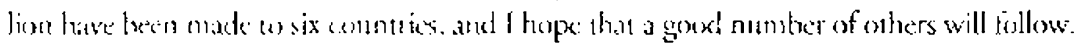

[ am convinced that if such a package of measures is promptly adopted, the crisis wil] be averted and those who have sutfered the most will sown emerge stronger than ever. I trust, however, that no one will want to stop there. We have lessons to leatn and an incemational financial sysem in need of rebuiding. These are the requirements for stable

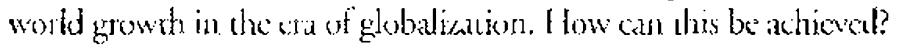

\section{STABLE GROWTH IN AN ERA OF GLOBAIIZATION}

Lec us begin by focusing our attention on the lessons of the Asian crisis. These lessons hold a messige for us all and should be put into practice especially in the most vulnerable

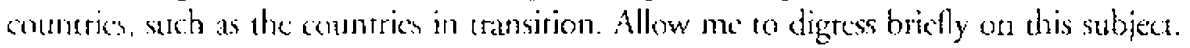
Cindoubtedly: 1997 brought goxd news for these countrics: positive growth was recorded for the first time in eight years, and the overall expansion is expected to strengthen this year and next. Regretcably, a number of these countries have been feeling the after shocks of the curmoil in Asid: their export prices have weakened, conditions in international capiral markers have become less tarorable. Asian imestors have sialed back invesments, and their curencies bave crome under attack.

The thallenge for us, therefore, is to assist these counteres in safeguarding and extending their progeses through sound micrneconomic policies and strucrural reforms aimed ar the strengthening of bank regulation and supervision: further privatization and enterprise reform: the nimimization of monopoly power; legat and institutional modernization; improwements in tax systems; health and educarion tedorms; pension reforms; and above all. good gonemancs "The IMIP will naturally continuc to support such programs. I

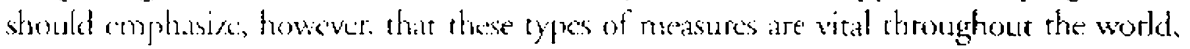
ard particularly in the conerging countries wishing to obrain financing fom golol capital mukets.

\section{So bow' can we make the world less prone to financial crises?}

What kind of new anchirecoute of the global sysem could atheve this? Le me describe for you four areas of reform on which the IMF has been asked to work. 
First, wic must continue our efforts to make Fund surveillance more effective and to enhance transparency in international finance. Indeed, transparency is the golden rule for a globalized economy. If the IMF receives the necessary resources, it can play a central role in crisis prevention by encouraging members to strengthen their macrocconomic policies and financial sectors. The IMF must now step up its efforts on surveillance of the financial sector, capital tlows, and the risks posed by a sudden reversal of capital flows. Work is also underway to develop a "tiered response," whereby countries that are believed to be seriously off course in their policies would be given increasingly strong warnings.

In order for our surveillance to be effective, however, data provision needs to be timely; accurate, and comprehensive. Thus, the IMF has decided to be more dernanding about the coverage and quality of the data provided to us and communicared to the markets.

Sccond, financial and banking systems, as well as their supervision, must be strengthened. For some time now, the Fund has been working to help disseminate a set of "best practices" in the banking areas developed by the Basle Committee so that standards and practices that have worked well in some countries con be adapted and applied in others. These efforts will now be stepped up.

Third, we need to establish more effective procedures to involve the private sector in preventing and resolving debt crises. Clearly, better ways must be found to involve private creditors at an early stage, in order to achieve equitable burden sharing vis-á-vis the official sector and to limit moral hazard.

Fourth, we must continue to liberalize international capital flows. This does not mean a mad rush to liberalization, regardless of the risks. What it does mean is liberalizing these flows in an orderly manncr that takes account of the specific circumstances prevailing within each individual country, without forgetting that the countries that take appropriate steps to achieve liberalization, while strengthening their economic equilibria and structures, will reap the rewards of global competition.

In the months and years ahead, we look forward to working with the international community, including all the countrics represented at the Council of Europe, on shaping this new global architecture. In the ultimate analysis, our goal is to ensure that the world and each country at its own particular stage of development - is afforded adequate prorection against the risks entailed by globalization and is helped to embrace the opportunities that globalization provides. This is the challenge that the countries in this forum have instructed the Fund ro address, and I thank them profoundly for their wholehearted supporr. 


\section{The IMF's Role in Today's Globalized World*}

W hat is the IMferchentrary to what I thoughe when I joined the inscitution, this is not it question on which educated people and policymakers have an inmediate and accurate response. In facr, according to popular opinion and indeed, the nakings of newspaper headlines - the Fund is simply a source of funancing or a medianism for crisis management. But this is wrong. as by tar one of our most inportant functions is what we call "surveillance" - a mechanism that offers the prospect of adkiressing economic difficulties before they teach crisis proportions. Surveillanoc is the process through which the IMF continulilly exchanges vicws with national atuthorities and thereby evaluates the policics, performance, and prospects of each member, and provides a candid assessment to the membership at lange an least once a year. Of course, the crises that are thereby prevented generally go unnoriced but the imporance of this surveillance in promoring economic growth and findacial stability cannot be overstated.

What kind of policy advice do we give? Throughout our history, we have urged countries to pursue sound economic policies and by that I mean policies that promote growth through low intlation, sound money, proderni fiscal policics, and a sustainable curtent acount posirion. Advice that should sound farniliar to a German audience! Yet, as the economic latdscape bats thanged, we have hroadened the scope of our advice to incluke other elements . what we all second generarion reforms - that are also vital for economic growth and financial stability. 'I hese include:

- reductions in unprotuccive grovernment spending;

- higher sperading on prinary health carc and education; and adequate social protection for rlac poor. she unemployed. and other vulnerable groups:

- the creation of a nore lewel playing fiekd for private sector activity, by increasing openness, stej)ping top privutioation, dismantling monopoliss, and serting up simpler, mote transpanent regulaion systems:

- stronger baukang ssitens that protect depositnus. spectally small savers, and reduce risks for shareholder ind anditors by entoring strict prodential standards and information disclosure rexpurentents;

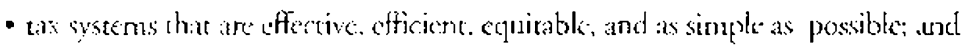

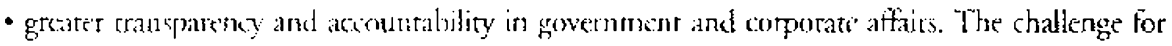
us is to give these issues the proper attention which ar be critical for the sustainability of maciosconmic peslicies - while kecping scrongly tocased, as part of our permaneni task of sur. veill:unce on the paramount objectires of stakility in its incemal and external aspects.

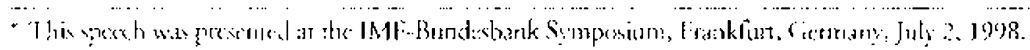


Beyond that, of course, there is our responsibility for helping member countries adapt to changing circumstances. And if this had not been our reading of our mandate, our membership would have been promat - and has been prompt - in asking us to take on this responsibility: in the 1970s, for helping oil exporters recycle their surpluses and helping others finance their vil-related deficits; in the $1980 \mathrm{~s}$, for helping Latin America overcome its debe crisis; in 1989 and the early 1990s, for helping the transition countries of eastern Europe and the former Soviet Union overcome the legacy of central planxing; and in lare 1994 and early 1995, for helping Mexico, and with it probably Latin America, avert financial collapse.

\section{HELPING COUNTRIES TO ADJUST}

Ihese days, we remain quite active in Russia and in many economies in transition, where we are trying to bolster reform efforts: in Africa, where we are helping to secure a renaissance after two lost decades; and in Asia. where we are trying to contain the current financial crisis. Let ine take these areas of the world one at a time.

From the earliest days of the rransition, the IMF has been helping to underpin reform efforts in the transition economies with policy advice, technical assistance, and financial support - and to mobilize financing from other sources. From 1990 to early 1998, IMF commitments to these economies totaled about $\$ 41.3$ billion. And the transition cconomies share of IMF' rechnical assistance rose from a lirtle over a quarter in 1992 to nearly 40 percest in 1995, and is now srill almost one third. Moreover, by the end of last month, the JVT (Joint Vicnna Institute) -- which was set up in 1992 by the IMF and several other multilateral institutions - had provided training to over 9,300 participants from 33 transition countries.

How are these countries faring! Undoubtedly, 1997 brought good news: positive growth was recorded for the first time in ejght years, and the overall expansion is expected to strengthen this year and nexr. But regrettably, a number of these countries have been feeling the aftershocks of the recent turmoil in Fast Asia: their export prices have weakened, conditions in infernational capital markcts have become less favorable, Asian investors have scaled back invesrments, and their currencies have come under attack.

The challenge for us, therefore, is to assist the transition economies in safeguarding and extending their progress through sound macrocconomic policies and - with the support of EBRD (Luropean Bank for Reconstruction and Development) and the World Bank * the second generation reforms that I have already mentioned. The IMF will nautrafly continuc to support such programs. Indeed, these types of measures are vital throughout the world. especially for emerging countries wishing to accsss global capital markets. It is interesting to recall that ar the beginning of the 1990s-a passionate debate developed: weten't we too tough pressing too nuch for low inflation and speedy reforn? Now the response is clear: the lastest countries in adjusting and reforming are now the strongest in growing and in withstanding the crisis. A lesson worth remembering.

As for Africa, we are stepping up our effors to help this continent avoid marginaliza- 
cion and accelerate growth in four key ways:

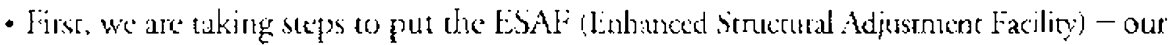
concessionad lending window -- on a self-ststaned footing so that we an continate to support reform efferts in Africa, and inded, in orher low-income countries, over the long term. W' are alio exploring wavs that the ESAF an serve the deseloping world betrex, drawing un lindings of tecent internal and external evaluations. Working closely with the World Bink, we shall be raking a tresh look at wys to accelerate public enterprise and finaticial secor tetoms: improse the assessment of median-term investment nads and appacity to abosh external financing; and identify potential adverse social

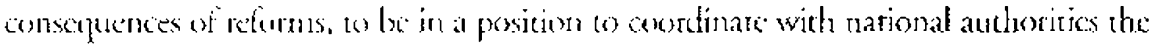
appropriate tapid, affective responses. And we shall certainly be looking at approaches that can help governnonts rake ownership of programs, and truly all them their own.

- Secund. we tare been moving swiftly to implement our joint HIPC (Heavily Indebted Poon (ountries inituative with the World Bank for the beatrily indebted poor conntries.

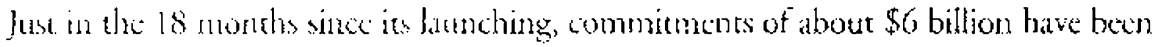

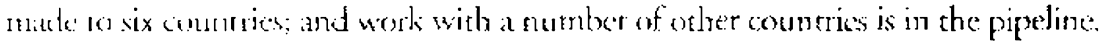

- Thind, we: the yars the INIF has provided assistance to countries that have experienced political rurmoil. sitil unrese, or international armod conflict -- and since 1995 , we have had a spcitial policy tir provide emergency post-conflict assistance. BosniaHerregovina was the tirst connesy to benefit from this new policy in late 1995, and Rwanda, Albaria, and lajikisan have also recived such assistance. The Republic of

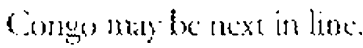

- Fourth, dhe IMI stands rady to continue to proude-and intensify-our training and technical assistmie for capacity building and institutional reform in Africa and low-income countries elsewhere. Pertaps onc of the most sncouraging signs is the

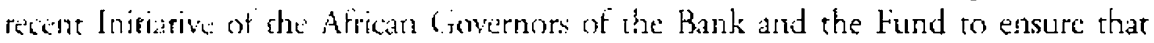
capacity huilding is hercetoth an integral prat if Africa's development agenda. In this

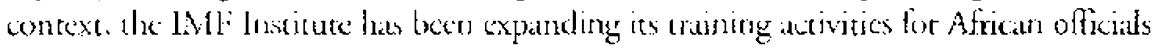

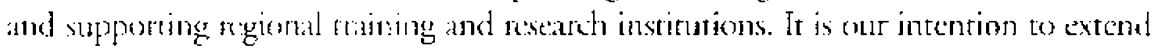

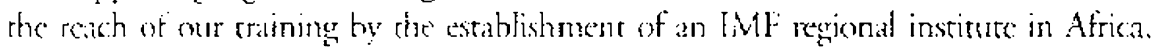
joinfly with maining partners in the region, iust as we have done tor the cransition economics by establishing the JVI and by putting in place the IMF - Singapore Regingal Triming lnstitute.

\section{HEIPING COLINTRIFS IN CRISIS}

Tiurting to Last Asia, the fint question here is what wene wrong? How could events unfisd as they did atter severa! decades of such outstanding pertotnance, in terms of growth and poverty reduction the answer is that there was anothet side to the so-called mirake, fn a glotolized conomy; a I suggested when talking about the scope for survel-

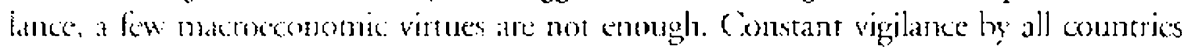


must be maintained over all the socioeconomic parameters. The soundness of the banking system, in particular, must be monitored at all times. The unsustainable accumulation of short-term financing must be avoided. And grear care must be taken to ensure that governments conduct their affairs in an imeproachable and transparent manner and that all forms of corruption, favoritism, neporism, and, if I may use the expression, "cronyism" are shunned.

But let us not single out the Asian countries alone. These missing elements exist to a degree everywhere. And Asia's problems would not have reached such proportions if financial institutions operating in the international markets had not taken excessive risks.

What is the IMF doing to contain the crisis? As soon as it was called upon, the IMF moved quickly to help Thailand, then Indonesia, and then Korea formulate reform programs aimed at tackling the roots of their problems and restoring investor confidence. In view of the narure of the crisis, these programs had to go far beyond addressing the major fiscal, monetary, or external balances. Their aim is to strengthen financial systems, improve governance and transparency, restore economic comperitiveness, and modernize the legal and regulatory environment.

Io provide the breathing space in which these cfforts could go forward-as, of course, it takes time to turn around a situation where major structural transformations are called for-we had to matshal catalytic, but adas, sizable financial support, and convince public and private creditors to alke their share in the burden of rebuilding the creditworthiness of these countries. I must also mention a much less spectacular, but equally important, efforr, which is to help other countries that were being threatened with contagion to strcngthen their macroeconomic fundamentals and their conomic structures. This explains why, at the prescret time, 55 countries around the world are applying IMF pregrams and 28 more - for a toral of 83 countrics - are having more or less advanced negoriations with us: the effort at strengthening economic structures with IMF stpport is truly widespread in the world!

But in recent weeks, a new crisis--a crisis within the crisis-has emerged with the weakness of the yen. This new development reflects a serious lack of confidence, provoked in part by recessionary conditions in Japan, as well as the crisis facing its financial institutions. Clearly, the fall of the yen is nor unrelated to the Asian crisis, but it could also seriously jeopardize the ongoing recovery of the economies that were hit firss. And it adds to the market instability that is again affecting other countries within the region, as well as some countries, including Russia, outside it. 'I hus, Japan must now move aggressively and quickly to rehabilitare its banking sector, to adopt policies--including reforms that would provide significant tax rclief - that ensure that fiscal stimulus is not withdrawn too quickly next year, and to open up and dexegulatc its cconomy. Hcre, 100, I should add that the rund is closely involved through its surveillance process.

Are we creating a moral hazard for borrowers and investors? As for borrowers, there is agreement, I believe, that no country would deliberately pursue reckless policies because it thought the IMF would bail it out in the event of a crisis. The political cost would simply be too great. As for investors, the debate is going on, and it is a healthy onc. But even if I frequenuly play devil's advocate for myself and my colleagues in the Fund, I always 
end up conduding that these prograns are hardly bailouts. Many private investors are taking heavy losses. With stock markcts and cxchange rates plunging, foreign cquity investots have lost nearly three quarters if nor more of the value of their equity holdings in some markets. Many firms and financial institusions will go banknupt, and their kenders will not be repaid. Morcover, carnings reports indicate that, overal, the Asian crisis has been very costly for many foreign commercial banks.

That being said, it is true that some short-term private creditors are being at least partly protected. Efforts should now he made to involve the private sector in resolving both sovereign and private debt problems. not just sovercign ones. But please remember that, in any casci, surcly the global incerst lics in containing and overcoming this crisis as quickly as possible.

This is, Mr. Chairmin, what keeps us busy at this very moment. But that is not all. There is anomet feamure of the halt cennury long life of the Fund, which moday keeps us cren busier: namely, the fact that we ate newer allowed to wait for the end of a crisis of scart thinking about how ro reinforce the system to avoid the next. I'his is what we now all, rather porrupously, strengthening the architecoure.

\section{STRENGTHENING THE ARCHITECTURE}

In view of the cnormous human and economic cost of the Asia crisis, no wonder we hear nany radical suggestions as to how to avoid such losses in the future. There atre calls for the international finakial sysem to do a better job of predicting and preventing crises, addressing their social impace mose offectively stopping speculators and properly regulating this "casino economy," secing to it that investors bear the futl costs of their mistakes, stabilizing the international monetary system, providing for more polinical accountability of our institution, ets., etc.

We annor deny the basic justification of these - at times vociferous - calls for change. No doube there afe at laast some elements of validity in cach of them. Taken engether, they tell us that world public opinion cxpects its leaders not necessarily to redesign everything from scratch, as if we were back to Breton Woods; but neither should we linnit ourselves co somis plumbing and interior decorating of the ofd mansion.

As tesponsjble architects, what can we come up with? I would like to suggest five areas where we should concentrate our etforts. And in our discussions today, I look forward to hearing the views of participants on these and any other areas they consider innortant.

- lirst, we must continute our efforts a make Fund surveillance more effective, as Fund surveillance will continue to play a crucial role in finture crisis prevention. We must intensify our monitoring of tinancial sector and capital account developments, including the risks posed by a sudden reversal of capital flows. che rapid accumulacion of short-term extermal detrt: and unhedged exposate to currency tluctuations. We must also monitor more closely makket views and perspectives, and give greater atcontion to policy interdepondence and risks of contagion.

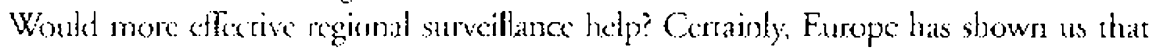


regional surveillance and peer pressure can produce an impressive degree of macroeconomic convergence. And while the instruments of regional cooperation are not as well developed in sther regions, as in Europe, their combined experiences suggest that there is wonsiderable scope for improving policies when neighboring countries get together on a regular basis to encourage one another-- and, at times, to excrt some peer pressure on one another - to pursue sound policies. For that reason, it is very encouraging to see such initiatives under way in Asia, and the Fund stands ready to contribute irs technical expertise to these efforts, as it already doxs in the $G-7$ and other fora.

We also need to develop a "tiered response," wheteby countries that are believed to be seriously off course in their policies would be given increasingly strong wantings. Here, we want ro draw on the lessons from the Asian crisis, and the experience that contidential warnings from the Fund are not always heeled. Addressing an audience in this country, where fortall is a favorite pastime, I do not need to emphasize how important it is to know exactly when the referee has shown a yellow card and how many yellow cards are permitted! We adso have in our Articles of Agreement the red card of going public with our assessments, but using this card could precipitate the crisis we seek to avoid. So ats good referees, we would try to keep the red card for truly unacceptable persistence in wrongdoing.

- Second. in order for our surveillance to be offective, we must improve the availability and transparency of information. In recent years, the IMF has taken numerous steps to enhance transparency and openness, including the establishment of standards to guide countries in publishing a regular and timely flow of comprehensive economic and financial data. Already, 47 countries have subscribed to the Special Data Dissemination Standard, which provides guidance to countries participaring in internarional markets, or aspiring to do so. We are now in the process of developing proposals for strengthening the standard, especially in the areas of intermational reserves, by including reserve-related liabilities and central bank derivative transactions, and private external debt, particularly short-term debt. We have also recently adopted a code of good practices on fiscal transparency, and looking ahead, we plan to develop a similar code with respect to financial and monctary policies.

Let me add that the Fund tries to practice the transparency it preaches: our Website on the Internet tries to answer just about any questions one may have on the Fund. It allows access, for example, to the condusion of the Article IV consultations by the Execurive Board in the form of Press Information Notices, and the letters of intent of a growing number of countries. And we will continue en post a wealth of data and other information. But to atl those with an "unbearable lighencss" who concinuc to complain about the so-called culture of secrecy of the Fund, I would like to ask: how could we do our job without preserving a sufficient confidentiality so as not to jeopardize the candor and comprehensiveness of policy discussions or to contribute to marker scares?

- Third, we must strengthen financial and banking systems, as well as their supervision. For some time now, the Fund has been working to help disseminate the set of "best pracvices" in the banking supervision area- as developed by the Basle Comminee $\cdots$ so that standards and practices that have worked well in some countries can be adapted and 
applied in others. In accord now with the wishes of the Fund's interim Committee, thesc efforts will be stepled up and broadened to cover oher intportant areas, such as accounting: aluditing: disclosure, asset valuation, bankrupicy, and corporate governanse: domains, of course, where the definition of standards will have to be the responsthility of other relevant internarional agencis.

- Fourth. we need to establish more effective procedures to involve the private sector in preventing and resolving debt crises. Olearly; betier ways nust be found to involve private credios's at an warly srage, in order to achice cquitable burden sharing vis-a-vis the official sector and to limit moral hazad. Theis is a difficult issuce but one that nuse now be racked.

- Fitth, as countries open their economies wo forcign capital, we must encourage them to liberalize apital account flows in a prudent and properly sequenced way that will maxjmize the benctits and minimize the risks of fieer capital movements. To this end, work is under way on an amendrnent to the IMF's chanter that woukd make the orderly liberalization of capital mowements one of the purposes of the Fund and extend its jurisdicrion

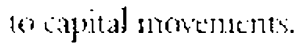

As T woukdn't like wo conclude on an cxcecdingly parochial note. I will only mention is parsing the nowd os entance the effectiveness of multilateral instinutions, which indudes ensuring that they hase sutficient resources to do their jobs. On dhis score, I welcome the positive example Grimany has set by consenting already to its share of the IMF quora increas: being proposal by the international community. With our usable resources now

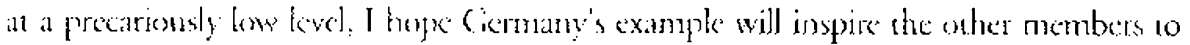
quickly tollow suit.

Before comiluding, I woukd like ro sugges how the membership, and particularly our leading members, coutd teest help us at this ditficult jincturt. Ot course, for me, this is a familiar rask, as not that long ago, when I served as a central bank governor. I was on the other side ot the rable sending instrucions wo my representarive at we board ot the IMt:

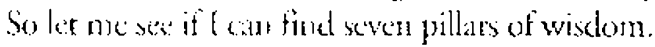

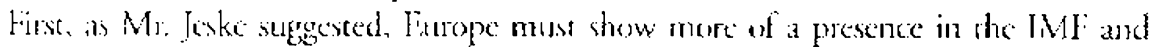
take heed on its responsibility as the IMF's biggese group of shateholders. resisting the complation to abandon itself ro a benigia neglect of ous instirution.

Second, agian, recilling my former role, in recommending tonghness to the IMIF; burspe crust sick also with this message ever when protege ate on the spot, and act with the ewen-hindeduess that you resommend to us.

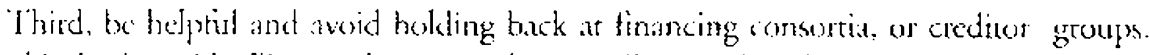
And indred, awosd teiling ws that we are late in calling oreditors' groups when you are not that inferesteat in joining them.

Fourth, svoid undercuting us, eren if it's done with the best possible intentions, by designing new schemes or new institutions - the last aratar of that being, for instance. the

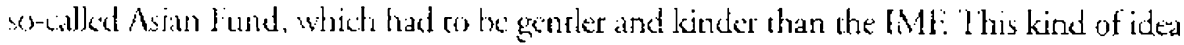
too olien griven countries in difficulty the foding that they can escape the hard, but indis-

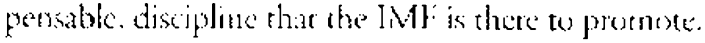

Fith, the man sharchokders of the IMF shouk help us as muk as they can in our ket 
task of surveillance: in helping us, in warning us when they see things we possibly don't perceive sufficiently, in emphasizing our message to the rest of the world, and in not doing the opposite - namely saying yes, yes, the IMF says that, but don't worry, we will help you find a solution.

Sixch, and by far the most important, you must compere for excellence in your eco nomic policymaking, not just for the sake of your people but also for the sake of the world. We need this example!

And seventh-- as you are so frequently giving the IMF the impossible task of squaring circles-please give us also generously, as the President of the Bundesbank did this morning, the benefit of the doube and the benefit of your friendly support, in spite of our wellknown flaws and lack of infallibility.

Well, together, these sever pillars and the IMF's five points (plus one') sum up to a rather ambrious agenda. But ir is an agenda that needs pursuing in these turbulent times. For without a more stable economic and financial system, we will be left adrift, unable to take on the challenges of the twenty-first century. But, Mr. Chairman, if this were to materialize, I am sure we could count on you to call a new seminar, this time for reinventing the truc LMF, which Germany has so faichfully supported for so many yeuts. 